\title{
George Santayana, The Genteel Tradition in American Philosophy and Character and Opinion in the United States
}

\author{
Edited and with an Introduction by James Seaton. New Haven and London: Yale \\ University Press, 2009. 200pp. \$16.00. ISBN-10: 0300116659; ISBN-13: 978-0300116656
}

\author{
Krzysztof (Chris) Piotr Skowronski
}

Published online: 22 July 2010

(C) The Author(s) 2010. This article is published with open access at Springerlink.com

The re-publishing of George Santayana's two most significant works on America and American culture in Rethinking the Western Tradition series makes a great deal of sense. Santayana (1863-1952), philosopher, best-selling author, poet, man of letters, and humanist, in his numerous books provided us not only with a system of philosophy but also with a profound criticism of Western culture. As a Spanish-American thinker, he skillfully applied his cultural in-betweenness, not to mention his genial insights, to make his readers reconsider the tradition of the Western World and the contemporary challenges that had to be faced. He devoted much attention to American culture and, in this regard, he shaped his thought predominantly in relation to transcendentalism (Ralph Waldo Emerson) and pragmatism (William James, Josiah Royce, John Dewey). It should be added, however, that Santayana also sought a redefinition of his native Spanish culture-so that his intellectual links with Generation 1898, Spain's momentous philosophical and literary movement, have frequently been studied by Spanish scholars. Last but not least, he focused on other cultural issues in terms of their ethnic character, cultural background, and national context; thus, he wrote, for example, about egotism in German philosophy (in Egotism in German Philosophy, 1915), about the British character, German freedom (both in Soliloquies in England, 1922), English liberty and American character (both in Character and Opinion in The United States, 1920).

The present volume presents an important part of Santayana's cultural criticism of America, that is "The

\section{K. P. Skowronski $(\bowtie)$}

Instytut Filozofii, Uniwersytet Opolski,

U1., Katowicka 89,

45-061 Opole, Poland

e-mail: skris69@yahoo.com
Genteel Tradition in American Philosophy" (1911) and Character and Opinion in the United States along with commenting essays by some excellent scholars. Although this is not all that Santayana had to say about Americahis lengthy novel The Last Puritan (1935) should be remembered here in the first instance-, we can say that the present volume is rich enough to elaborately show Santayana's approach to America and American culture in a broad and penetrating way. For example, we can read in these two works, Santayana's attempt to re-interpret American culture by famously saying that "The American Will inhabits the sky-scraper; the American Intellect inhabits the colonial mansion. (...) The one is all aggressive enterprise; the other is all genteel tradition (p. 4)." His idea of "the Genteel Tradition," as opposed to the "crude but vital America," can be helpful in understanding the American mind in the 19th century and at the beginning of the 20th century. What he witnessed upon his arrival in New England as a child in 1872, was the passage from the old genteel Boston to the new industrial one along with the growing split in values, aims, and experiences, the split he commented upon in his cultural criticism. Namely, there emerged a new type of American mentality, "the untrained, pushing, cosmopolitan orphan, cock-sure in manner but not too sure in his morality, to whom the old Yankee, with his sour integrity, is almost a foreigner (p. 30)." The American mentality became split because the old and noble categories of America's high culture were applied to the new and down-to-earth challenges of the America of enterprise and expansion: "Was not 'increase' in the Bible, a synonym to 'benefit'? Was not 'abundance' the same, or almost the same as happiness? (p. 30)"

The present volume is the more interesting in that Santayana's texts are copiously commented upon by some 
excellent scholars and writers-James Seaton, Wilfred M. McClay, John Lachs, and Roger Kimball-so that it attractively provides the readers with more insight into Santayana and, at the same time, proposes some modes for the interpretation of Santayana's ideas. Thanks to these essays following the main text, as well as the Introduction that is prior to it, we have a well balanced book; Santayana's major texts on American culture are accompanied by the studies and comments that constitute more or less one third of the whole volume, and, which more importantly, are competently composed and clearly arranged.

In the tersely and penetratingly written Introduction entitled "George Santayana-The Philosopher as Cultural Critic," the editor of the volume, James Seaton, succinctly provides the readers with biographical data, including Santayana's cosmopolitan background along with the American and Spanish traits in the history of his family; moreover, he pictures the contemporary philosophical scene on which he describes Santayana in relation to the major figures of American culture and philosophy (William James, Josiah Royce, John Dewey, Wallace Stevens, Stanley Fish) as well as those of Continental philosophy (Jacques Derrida, Henri Bergson) in order to place him on the philosophical stage and to detect the continuing relevance of his thought. Also, he presents in a very clear way some characteristics of Santayana's cultural criticism, one of them being what I should call Santayana's inbetweenness, that is his "unusual position as both an outsider and an insider in American society (p. xi)." All this makes Santayana's analysis of American culture, especially those in Character and Opinion, as Seaton puts it, "a living portrait whose truth remains pertinent today (p. xxiv)." Indeed, Seaton provides examples for Santayana's continuing relevance as a cultural critic. Thus, Seaton sketches William James's anticipation of today's multiculturalism and recalls Stanley Fish's ideas of "boutique multiculturalism" and "strong multiculturalism" so as to provide an interesting context for Santayana's stance; here, especially inspiring seems to me Seaton's analysis of the reasons for James's multiculturalism and for Santayana's skepticism to it as well as Santayana's criticism of James for avoiding a clear articulation of his "liberal Protestantism" as being the moral, cultural, religious, and axiological basis for James's pragmatism. James (and Royce) saw the world as a battlefield in which a constant fight between good and evil takes place; in this fight any neutrality-for example an aesthetic contemplation of the world as it is, along with the intellectual understanding of its various perfections (both of which Santayana advocated) - is hardly possible and everyone is required to choose sides.

In Seaton's other essay, "The Genteel Tradition and English Liberty," he explains why we should go on thinking about Santayana's idea of "the Genteel Tradition" many years after it factually lost its meaning. Seaton's answer (interestingly vindicated) to this is, that "the parallel to the genteel tradition today is not with those whose moral views are based on their religious faith but rather with the postmodernist academic left, which has reprised the genteel tradition's convenient but incongruous alliance of epistemological skepticism with moral certainty (p. 164). I leave the reader to the author's explanation, and pass, very briefly indeed, to the other essays in the volume.

In his essay entitled "The Unclaimed legacy of George Santayana," Wilfred M. McClay pays attention, among other things, to Santayana's excellent and sophisticated style of writing along with his "astonishing facility in tapping the revelatory power of metaphor and simile (p. 123)." What McClay labels as "reflective literature (p. 124)," and what I should name as literary philosophy, is a kind of writing that touches philosophical issues by means of a literary form with this form having worth in itself. Santayana, as its masterful exemplar, can be put, in my view, side by side, with Michael de Montaigne, Ralph Waldo Emerson, and Marcel Proust. McClay rightly warns as against ignoring this dimension of Santayana's works in the name of searching for some crude ideas and essential theses to be extracted from his works; having gained just the philosophical insight into his work, we will lose its literary charm, its reflective spirit, its sophisticated irony-very strong points in Santayana's message. As regards Santayana's criticism of America, a "broad-brush account of the American mind that Americans have never quite been able to muster for themselves (p. 124)," McClay explains the issue put forward in the title of his paper, that is, what is the unclaimed legacy of Santayana. Namely, it is his vantage point in observing America, that is "the detachment necessary to see American life without first accepting its premises (p. 129)." This means, that without America's excitement about progress, success, activity, and pragmatism Santayana could, and still can, propose an insight into the richness and the beauty of things that have long ago lost their social attraction and down-to-earth application.

John Lachs, in an essay "Understanding America," speculates why the representatives of conflicting nations, like Hindus and Pakistanis, Israelis and Palestinians, and Serbs and Croats, live non-violent lives in America. Interestingly, Santayana, says Lachs, can provide some part of the explanation, that is to say, his notions of absolute liberty and English liberty.

The former allows no compromise, sees the infinite difference between right and wrong, and is ready to destroy all those who are unfaithful to the nation's tradition; its despotism requires unhesitant patriotism and loyalty. The latter, however, so typical of America, "thrives on the spirit 
of compromise" (p. 152); its optimistic, cooperative, and tolerant character makes it possible for antagonized enemies in Europe or Asia to find a peaceful life, side by side each other, in America. Santayana could see this and, as Lachs puts it, he realized that the motivating force of American society has been its strong belief in hard work and in social progress within the community arranged according to the principles of English liberty (cf. 153).

Finally, Roger Kimball in "Mental Hygiene and Good Manners: The Contribution of George Santayana," associates, rightly in my view, Santayana's observations and reflections devoted to America with Alexis de Tocqueville's Democracy in America. Kimball is right in putting forward such a comparison, because, despite almost a half a century of difference in space between their (I mean: Tocqueville's and Santayana's) examinations of America as well in the character of these examinations and the national backgrounds of their authors, their conclusions strikingly dovetail. Both outsiders, penetrating observers, and commentators of America's cultural and political scene having their points of reference in high class, cultural and aristocratic Europe were impressed by America's vitality, dynamism, energy and, on the other hand, her ability to generate a diluted culture and indifference to intellectualism.

Let me conclude this short review by saying that Santayana saw America as an up-and-coming superpower. She started to become such at the very moment when Spain, Santayana's beloved motherland (he never quit his Spanish citizenship), lost its imperial status in the SpanishAmerican War of 1898, and Santayana witnessed this being at Harvard as a freshly appointed assistant professor at the
Philosophy Department at that time. As he saw the end of Imperial Spain, he also witnessed the nascence of Imperial America and, despite his harsh criticism, he also had much hope in her and much admiration, especially for her dynamism, optimism, vitality, and creativity, and the flexibility of the "social organization," or the arrangement of the political life within American democracy. Since American values have become global nowadays, and the processes of Americanization have reached all the countries of the world, many particular aspects of American culture have become a universal issue to be discussed by nonAmericans too. This way, understanding America is not just a challenge to Americans. I am positive that the present volume can be recommended to a broader audience than just Santayana scholars and even broader than American readers; hence, the book is recommended to all those - interested in philosophy, in cultural criticism, and the contemporary intellectual history - who live in all the places that have been influenced by America and the power of her culture.

Open Access This article is distributed under the terms of the Creative Commons Attribution Noncommercial License which permits any noncommercial use, distribution, and reproduction in any medium, provided the original author(s) and source are credited.

Krzysztof (Chris) Piotr Skowronski, PhD currently teaches Contemporary Philosophy, Aesthetics, Cultural Anthropology, Polish Philosophy, and American Philosophy at the Institute of Philosophy, Opole University, Poland. He is author of, among other works, Values and Powers. Rereading the Philosophy of American Pragmatism (Amsterdam-New York: Rodopi, 2009) and Santayana and America. Values, Liberties, Responsibility (Newcastle: Cambridge Scholars Publishing, 2007). 